\title{
Sandstone Composition and Provenance of the Nari Formation, Central Kirthar Fold belt, Pakistan
}

\author{
Zahoor Ahmed, Abdul Salam Khan*, Bilal Ahmed \\ Centre of Excellence in Mineralogy University of Balochistan, Quetta. \\ *Corresponding author email: asalamk cem@yahoo.com
}

\section{DOI: 10.2478/pjg-2020-0010}

\section{Abstract:}

The Oligocene-Early Miocene Nari Formation is widely distributed in the Kirthar thrust-fold belt. The formation in the study area is mainly consist of sandstone and shale. Field observations and detailed petrographic study reveal that these sandstones are mostly fine to medium grained, subangular to subrounded and poorly to moderately sorted. Detrital grains are dominantly quartz ranging in proportion 36-76\%, feldspar 7-17\% and lithic grains 1-13\%, reflecting that these sandstones are compositionally submature. Quartz is mostly monocrystalline with some polycrystalline grains. Feldspar is dominantly plagioclase (albite) with some alkali feldspar (orthoclase and microcline). Lithic fragments are siltstone, mudstone and chert. Biotite and muscovite are present as accessory minerals. Heavy minerals such as apatite, tourmaline, and zircon are present in trace amount. The QFL diagrams show that the sandstones of the Nari formation are subarkose and lithic subarkose. The QtFL, QmFLt ternary diagrams and paleocurrent direction suggest that the sediments were transported from the Indian shield exposed to the northeast of the Nari Basin.

Keywords: Petrography; Provenance; Nari Formation; Kirthar Fold Belt; Indian Sheild

\subsection{Introduction:}

Petrographic analysis can be used to classify siliciclastic sedimentary rocks and to trace provenance. Since detrital mineral components of such rocks preserve good information useful for interpretation of source rock characterization [1-7]. The original mineral composition of siliciclastic, particularly sandstones is the function of interaction of many factors like parent rock lithology, weathering, topography, climate, transportation, depositional environments and diagenetic processes [5, 8-11]. Other factor like recycling and mixing of sediment from multiple sources also influence the composition of sandstones. Different tectonic basins provide specific mineral components unique to that tectonic environment [5]. The present study was carried out to provide detailed petrographic analysis in order to determine mineral composition and construct provenance of the Nari Sandstone exposed in the Central Kirthar Fold-Belt, Balochistan, Pakistan. Previously no detailed petrographic study of the sandstones of the Nari Formation in the study area have been undertaken for classification and provenance of these sandstones.

\subsection{Geological Setting of the area}

The Kirthar range is characterized mostly by sedimentary successions, starting from Jurassic Ferozabad group to Holocene recent-sub recent rocks (Table 1). The Jurassic Ferozabad Group, was introduced [1]. The Jurassic Ferozabad Group is consist of three formations [1]. These are Kharrari Formation, Malikhore Formation and Anjira Formation. The Kharrari Formation is mainly composed of limestone, dolomite, sandstone, siltstone and shale [2]. The Malikhore Formation is mainly consist of thick-bedded limestone with subordinate shale and marl [2]. The Anjira Formation is consist of limestone thin to thick bedded locally interbedded with thin marl and shale beds [2]. Early-late Cretaceous Mona Jhal group unconformably overlies the Anjira Formation and is divided into Sembar, Goru, Parh and Maghal Kot Formations [1]. Sembar Formation is dominantly shale with subordinate siltstone and limestone [1].

Goru Formation is characterized by rhythmic alternation of limestone and shale [3]. Parh Limestone is predominantly composed of argillaceous and occasionally platy to slabby limestone [3]. The Maghal Kot Formation is composed of marl, shale and quartz rich sandstone [4]. Pab sandstone of Maastrichtian age is dominantly composed of quartzose sandstone with minor marl and mudstone [5,6]. The Khadro Formation, conformably overlying the Pab sandstone is consist of sandstone, shale and minor limestone beds [4,7]. Bara Formation of the Rani Kot group is dominantly composed of sandstone with minor shale and volcanic debris [8]. Lakhra Formation of Rani Kot group conformably overlies the Bara Formation is dominantly composed of limestone, sandstone and shale [3]. The Ghazij Formation dominantly is composed of mudstone, shale with subordinate sandstone, conglomerate and coal $[4,7]$.

The Kirthar Formation overlying the Ghazij Formation is dominantly limestone with minor shale and marl [3,7]. The Nari Formation is mainly consist of sandstones and interbedded shales [4]. The sandstone is fine to medium grained, in places coarse grained. Sandstone beds are thin to thick, displaying cross lamination, parallel lamination, grading and various types of sole marks. Shale shows intense bioturbation and burrows mostly horizontal. Early Miocene Gaj Formation conformably overlies the Nari Formation. It is composed of mudstone, limestone, sandstone and minor beds of conglomerate. The Pliocene Manchar Formation, uncomfortably overlying the Gaj Formation is predominantly sandstone, mudstone with minor conglomeratic beds [7]. The Pleistocene Dada conglomerates contains some sandstone intercalations.

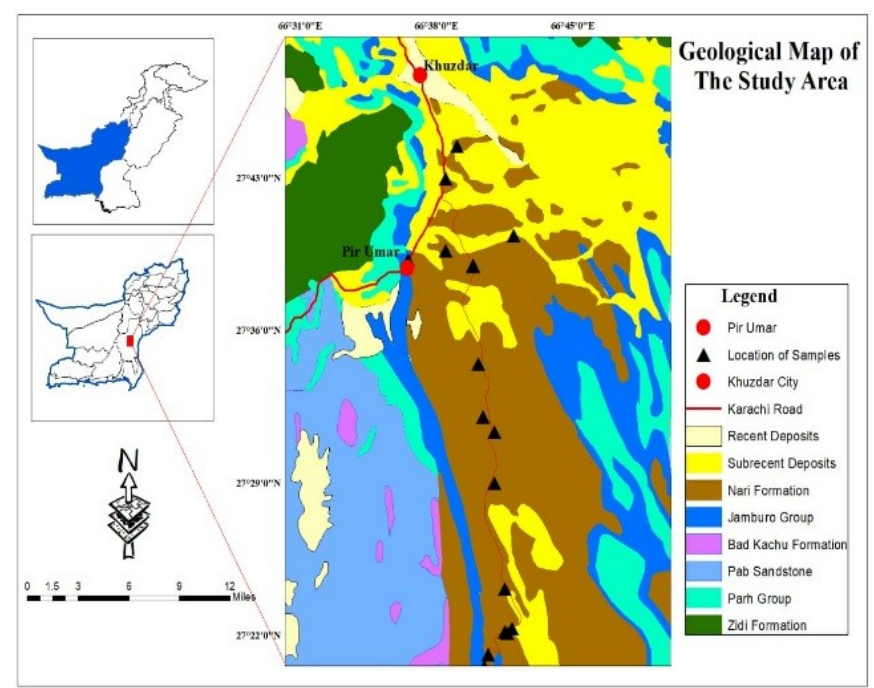


Figure 1: Geological map of the study area modified after [9]

Table 1: Stratigraphy of the Kirthar fold belt modified after [1,3,9].

\begin{tabular}{|c|c|c|c|c|}
\hline \multicolumn{2}{|l|}{ AGE } & GROUP & FORMATION & LITHOLOGY \\
\hline \multicolumn{2}{|c|}{ Holocene } & & Recent-Subrecent & Mixture of clay, sand and gravel \\
\hline \multicolumn{5}{|c|}{ Unconformity } \\
\hline \multicolumn{2}{|c|}{ Pleistocene } & & Dada Formation & Conglomerates with subordinate coarse grained sandstone \\
\hline \multicolumn{2}{|c|}{ Pliocene } & & Manchar Formation & $\begin{array}{l}\text { Sandstone, shale interbedded with subordinate } \\
\text { conglomerate }\end{array}$ \\
\hline \multicolumn{5}{|c|}{ Unconformity } \\
\hline \multicolumn{2}{|c|}{ Miocene } & & Gaj Formation & $\begin{array}{l}\text { Shale and sandstone with subordinate limestone and } \\
\text { conglomerate }\end{array}$ \\
\hline \multicolumn{2}{|c|}{ Oligocene } & & Nari formation & Sandstone interbedded with shale \\
\hline \multirow{2}{*}{ 巳ัّ } & & & Kirthar Formation & Fossiliferous limestone interbedded with shale and marl \\
\hline & & & Ghazij Formation & Shale is dominant with minor sandstone \\
\hline \multirow{3}{*}{ 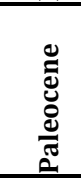 } & \multirow{3}{*}{\multicolumn{2}{|c|}{ Rani Kot Group }} & Lakhra Formation & Intraclastic limestone and shale \\
\hline & & & Bara Formation & Sandstone and shale \\
\hline & & & Khadro Formation & Sandstone, shale and marl \\
\hline \multirow{5}{*}{ 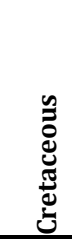 } & \multicolumn{2}{|c|}{ Maastrichtian-Campanian } & Pab Sandstone & Sandstone intercalated with marl and mudstone \\
\hline & \multirow{4}{*}{$\begin{array}{l}\text { (Early- } \\
\text { Late) }\end{array}$} & \multirow{4}{*}{ Mona Jhal Group } & Maghal Kot Formation & Marl, arenaceous limestone, mudstone and sandstone \\
\hline & & & Parh Limestone & Biomicrite limestone \\
\hline & & & Goru Formation & Micrite limestone with shale, siltstone and sandstone \\
\hline & & & Sembar Formation & Shale, siltstone and marl \\
\hline \multicolumn{5}{|c|}{ Unconformity } \\
\hline \multirow{3}{*}{ 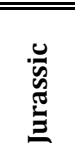 } & \multirow{3}{*}{ 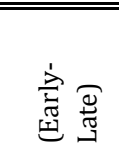 } & \multirow{3}{*}{$\begin{array}{l}\text { Ferozabad } \\
\text { Group }\end{array}$} & Anjira Formation & Limestone interbedded with shale and marl \\
\hline & & & Malikhore Formation & Oolitie limestone with subordinate shale and marl \\
\hline & & & Kharri Formation & Limestone, shale, marl and minor sandstone \\
\hline
\end{tabular}

\subsection{Materials and Methods}

Six stratigraphic sections of the Nari Formation were measured in the study area, and were described in detail, noting their sedimentary structures, texture and other features. 25 samples were collected from different horizons of Nari Formation for detailed petrography (Table 2). Petrographic analysis of 20 representative samples were carried out using the Leica petrographic microscope equipped with digital camera and automatic point counter. Minimum 300 points in each thin section were counted for the comparative proportion of mineral composition using Gazzi-Dickinson method [10-12]. Nomenclature of was used to determine the framework grains for siliciclastic sandstones (Table 3) [7]. For classification of sandstone ternary diagrams were used (Figure 3) and for provenance and tectonic settings of sandstone of the Nari Formation, ternary diagrams and were used (Figure 4) [10-14].

\subsection{Results}

\subsection{Texture}

Field observations and petrography of the Nari Formation reveal that the formation in the study area is consist of dominantly sandstone and shale. Limestone beds are present in the southern part of the Basin [15]. The sandstone is fine to medium grained, in places coarse grained, thin to thick bedded, in places massive, moderately sorted, framework grains are mostly subangular to subrounded (Figure 2A) with low to medium sphericity. Common sedimentary structures are parallel lamination, cross lamination, normal grading, flutes, load casts and grooves. It is mainly grain supported, with calcite cement $2-35 \%$ and ferruginous cement $1-9 \%$.

\subsection{Sandstone Composition}

The sandstones of the Nari Formation are mainly composed of quartz, feldspar and lithic grains. Biotite and muscovite present as accessory minerals and heavy minerals such as apatite, epidote, tourmaline and zircon are present in trace amount (Table 2).

\subsection{Quartz}

Quartz is found as the most common detrital mineral in sandstones of the Nari Formation, ranging from 36\% to 76\%. Quartz is mostly monocrystalline and shows uniform extinction (Figure 2B). Some of the quartz grains show undulose extinction. Polycrystalline Quartz are also present in minor amount (Figure 2B). The Quartz grains are commonly subangular to subrounded in shape.

\subsection{Feldspar}

Feldspar is the next abundant mineral in these sandstones ranging from 7 to $17 \%$. It is mostly plagioclase with minor amount of alkali feldspar (orthoclase and microcline). Plagioclase feldspar is characterised by perfect albite twining (Figure 2C), low relief and some show zoning whereas orthoclase and microcline feldspar show cross hatch and Carlsbad twining (Figure 2C). The orthoclase grains are usually cloudy and dirty. Some grains with perthitic and myrmekitic intergrowth texture were also observed in some thin sections (Figure 2D). The shape of feldspar grains are mostly subangular to subrounded, partially to completely altered to sericite and calcite. 


\subsection{Lithic grains}

Lithic grains are less common, ranging from 1 to $13 \%$ with an average of $6 \%$ (Table 2). Among the lithic fragments mudstone is the most common with minor amount of sandstone, siltstone, mudstone, limestone, volcanic igneous rocks and bioclasts. Bioclasts of foraminifer are also present most probably derived from older formations.

\subsection{Mica}

Mica in the form of biotite and muscovite are present up to 4\%. Biotite is more common than muscovite. They are present in the form of elongate and bended flakes. (Figure 2E, F). Some grains of muscovite are strained and altered to chlorite.

\subsection{Cement}

Calcite, quartz and hematite cement (Figure 2) is present ranging from 5-14\%, Calcite cement is more abundant, while one sample (ZA-33) contains $37 \%$ cement. Quartz overgrowth has also been observed in several thin section. Calcite replacing quartz and feldspar grains is common (Figure 2G).

\subsection{Heavy minerals}

Heavy minerals such as Zircon (Figure $2 \mathrm{H}$ ), tourmaline, apatite and epidote are present as accessary minerals. Brown leached material may indicate the presence of iron oxide.
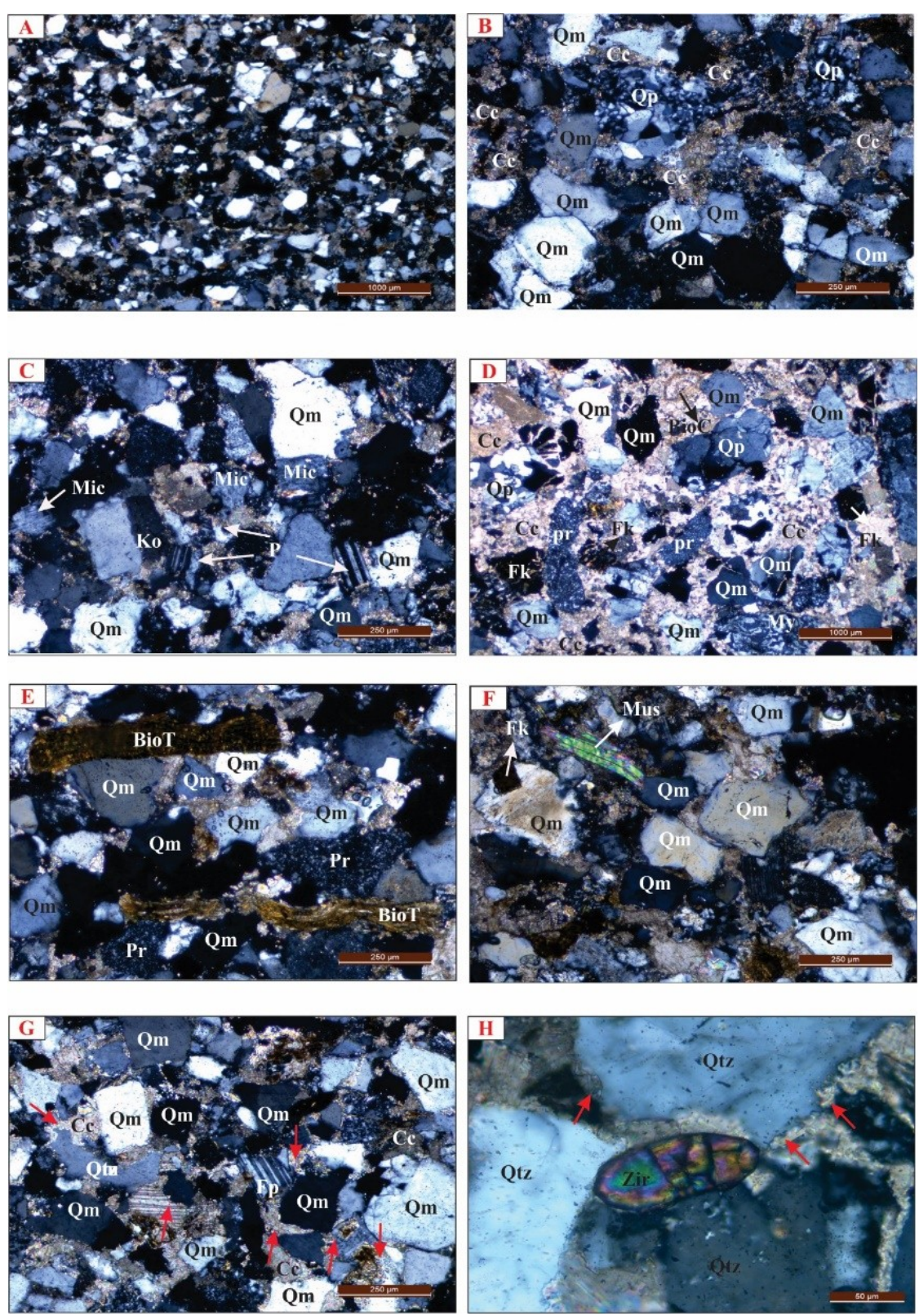

Figure 2: Photomicrographs of sandstones of the Nari Formation showing (A) moderately sorted, subangular to subrounded grains of quartz, (B) monocrystalline-Qm and polycrystalline-Qp quartz grains, (C) Albite-Al, Orthoclase-Or and Microcline-Mic grains, (D) perthetic-Pr and myrmekitic-My texture, (E) Biotite-BioT, (F) Muscovite-Mus, (G) Calcite replacing quartz and feldspar grains-red arrow, (H) Zircon grain, also note calcite replacing quartz. 
Table 2: Mineral composition of the Nari Sandstone.

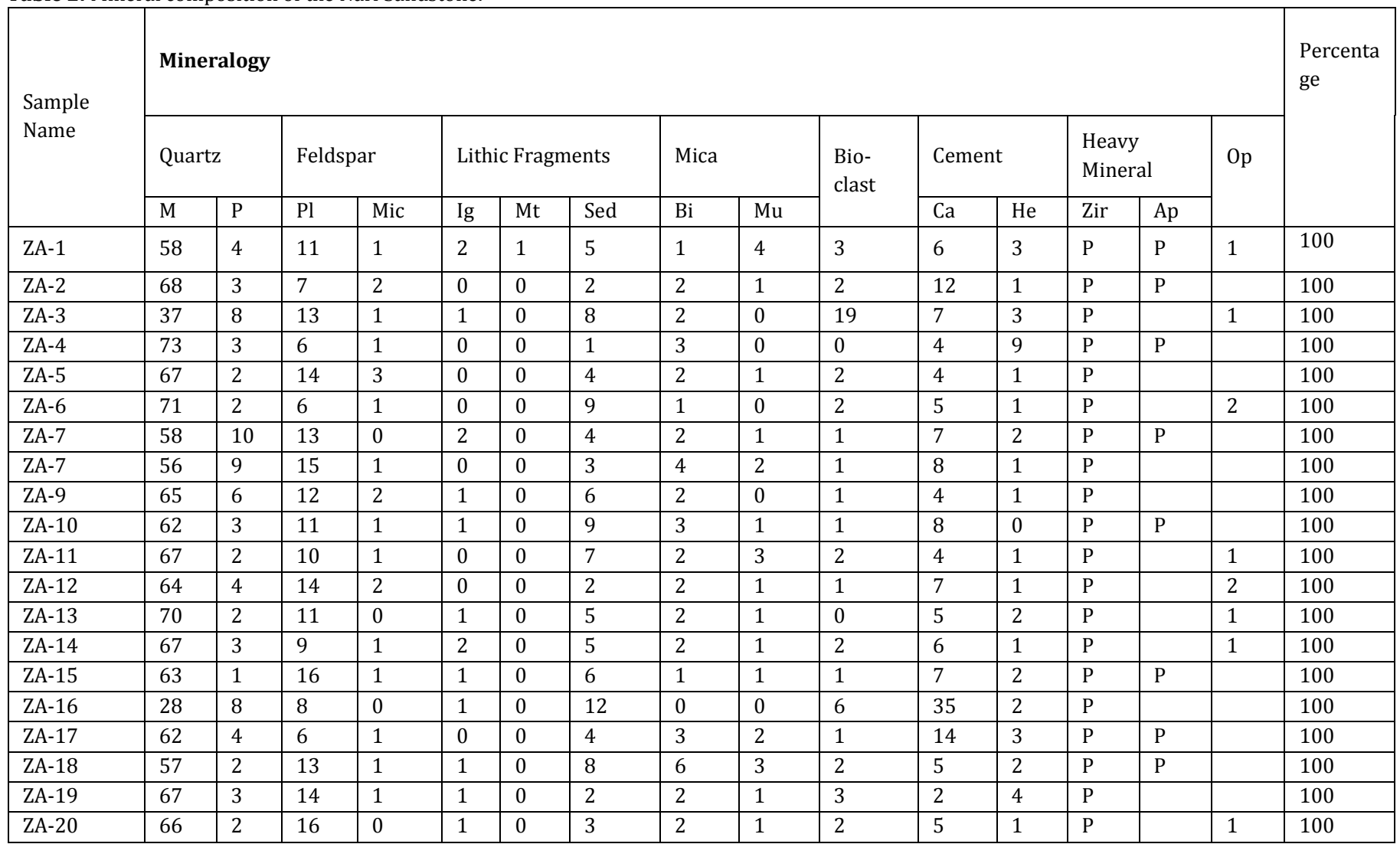

\subsection{Sandstone Classification of Nari Formation}

The values of recalculated detrital mineral composition of the studied thin sections (Table 3) were plotted into the ternary diagrams for classification of sandstones (Figure 3) fall in the field of subarkose and few samples fall in the field of lithic subarkose, indicating that the sandstones of the Nari Formation are mostly subarkose and with minor lithic suarkose, reflecting that these sandstones are compositionally submature [13,14].

Table 3: Recalculated modal point count data of sandstone of the Nari formation in the study area.

\begin{tabular}{|c|c|c|c|c|c|c|c|c|c|c|c|c|}
\hline \multirow[t]{2}{*}{ S.No } & \multicolumn{3}{|c|}{ Qm-F-Lt (\%) } & \multicolumn{3}{|c|}{ Qt-F-L (\%) } & \multicolumn{3}{|c|}{ Lm-Lv-Ls (\%) } & \multicolumn{3}{|c|}{ Qm-P-K (\%) } \\
\hline & $\mathrm{Qm}$ & F & $\mathrm{Lt}$ & $\mathrm{Qt}$ & $\mathrm{F}$ & $\mathrm{L}$ & $\mathrm{Lm}$ & LV & Ls & $\mathrm{Qm}$ & $P$ & $\mathrm{~K}$ \\
\hline ZA-1 & 74 & 15 & 10 & 76 & 15 & 10 & 12.5 & 25 & 63 & 86 & 13 & 1 \\
\hline ZA-2 & 86 & 11 & 3 & 87 & 11 & 2 & 0 & 0 & 100 & 91 & 7 & 2 \\
\hline ZA-3 & 62 & 23 & 15 & 66 & 21 & 13 & 0 & 11 & 89 & 81 & 17 & 1 \\
\hline ZA-4 & 90 & 9 & 1 & 90 & 8 & 1 & 0 & 0 & 100 & 93 & 6 & 1 \\
\hline ZA-5 & 76 & 19 & 5 & 77 & 19 & 4 & 0 & 0 & 100 & 82 & 15 & 3 \\
\hline ZA-6 & 82 & 8 & 10 & 82 & 8 & 10 & 0 & 0 & 100 & 92 & 7 & 1 \\
\hline ZA-7 & 75 & 17 & 8 & 78 & 15 & 7 & 0 & 33 & 67 & 85 & 15 & 0 \\
\hline ZA-7 & 75 & 21 & 4 & 77 & 19 & 4 & 0 & 0 & 100 & 82 & 17 & 1 \\
\hline ZA-9 & 76 & 16 & 8 & 77 & 15 & 8 & 0 & 14 & 86 & 84 & 13 & 2 \\
\hline ZA-10 & 74 & 14 & 12 & 75 & 14 & 11 & 0 & 10 & 90 & 86 & 13 & 1 \\
\hline ZA-11 & 79 & 13 & 8 & 79 & 13 & 8 & 0 & 0 & 100 & 88 & 11 & 1 \\
\hline ZA-12 & 78 & 20 & 2 & 79 & 19 & 2 & 0 & 0 & 100 & 83 & 15 & 2 \\
\hline ZA-13 & 80 & 13 & 7 & 81 & 12 & 7 & 0 & 17 & 83 & 88 & 12 & 0 \\
\hline ZA-14 & 80 & 12 & 8 & 80 & 11 & 8 & 0 & 29 & 71 & 89 & 10 & 1 \\
\hline ZA-15 & 72 & 20 & 8 & 73 & 19 & 8 & 0 & 14 & 86 & 81 & 18 & 1 \\
\hline ZA-16 & 57 & 16 & 27 & 63 & 14 & 23 & 0 & 8 & 92 & 88 & 12 & 0 \\
\hline ZA-17 & 85 & 10 & 5 & 86 & 9 & 5 & 0 & 0 & 100 & 92 & 7 & 1 \\
\hline ZA-18 & 71 & 18 & 11 & 72 & 17 & 11 & 0 & 11 & 89 & 84 & 15 & 1 \\
\hline ZA-19 & 79 & 18 & 4 & 80 & 17 & 3 & 0 & 33 & 67 & 84 & 15 & 1 \\
\hline ZA-20 & 77 & 19 & 5 & 77 & 18 & 5 & 0 & 25 & 75 & 83 & 17 & 0 \\
\hline
\end{tabular}


Table 4: Framework grain parameters [10].

\begin{tabular}{|l|l|}
\hline $\mathrm{Qt}=\mathrm{Qm}+\mathrm{Qp}$ & $\begin{array}{l}\mathrm{Qt}=\text { Total quartzose Grains. } \\
\mathrm{Qm}=\text { Monocrystalline Aphanitic Quartzose Graines. } \\
\mathrm{Qp}=\text { Pollycrystalline Aphanitic Quartzose Graines. }\end{array}$ \\
\hline F= P+ K & $\mathrm{F}=$ Total Feldspar Graines. \\
& $\mathrm{P}=$ Plagioclase Feldspar Graines. \\
& $\mathrm{K}=$ Orthoclase Feldspar Graines. \\
\hline Lt = Lm + Lv Ls & $\mathrm{Lt}=$ Total Unstable Aphanitic Lithic Graines. \\
& $\mathrm{Lm}=$ Metamorphic Aphanitic Lithic Graines. \\
& $\mathrm{Lv}=$ Volcanic And Hypabasal Aphanitic Lithic Graines. \\
& Ls = Sedimentary Aphanitic Lithic Graines + Extrabasinal Carbonate Graines. \\
\hline
\end{tabular}
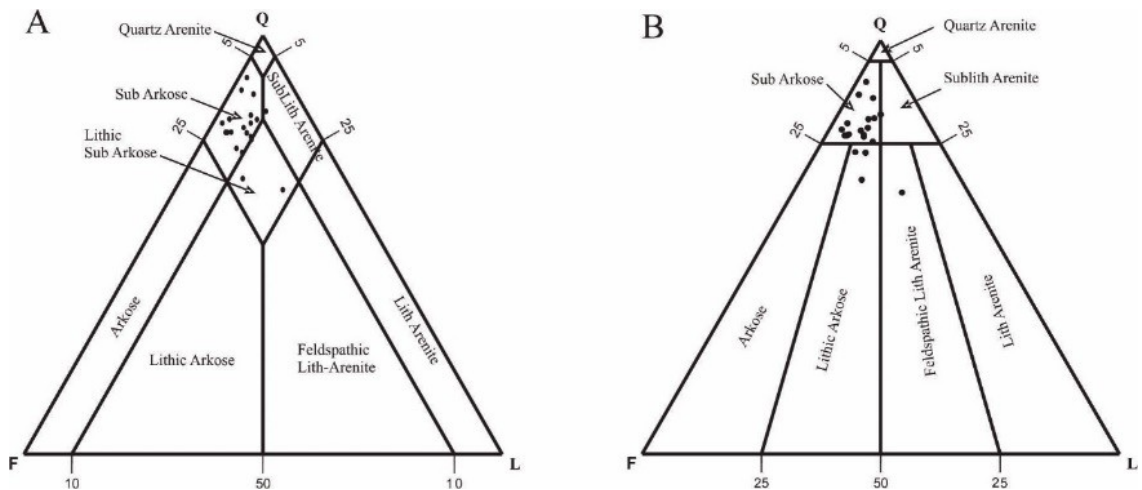

Figure 3: QFL ternary diagrams (A-Pettijhone, 1975 and B-Folk, 1980) for sandstone classification of Nari Formation.

\subsection{Interpretation and Discussion}

\subsection{Provenance and Tectonic Settings}

To interpret sandstone provinance and tectonic setting of the ancient sedimentary basins with the help of the quantitative detrital modes, calculated from point counts of thin section is well established $[10,11,16]$. Sandstone composition is greatly affected by parent rock type, tectonic setting, climate, topography of the source area, mechanism of transport, depositional environament and diagenesis [10-17]. Prolong weathering produces sandstone depleted with unstable minerals such as feldpar and mafic minerals and enriched with stable minerals such as quartz. Sandstone composition is also modified during transportation from source to depositional site by eliminating the unstable minerals. Mixing of sediment from multiple source and addition of sediment like bioclast, glauconite within basin followed by diagenesis further modify final composition of sandstone [17-20]. Major categories of provinance include Craton Interior, Transitional Continental, Basement Uplift, Magmatic Arc (Dissected Arc and Undissected Arc) and recycled orogen $[10,11,16]$.

Using the QtFL plot, the detrital mineral composition of sandstone of the Nari formation fall in craton interior and recycaled orogen field (Figure 4A) and the data plotted in the QmFLt ternary diagrams, fall in the field of craton interior and transitional continetal bolck provenance (Figure 4B) indicating that the sandstones of the Nari formation were derived mostly from shield areas and some from uplifted basement and recycle orogen s provenance [16]. The sheild areas, commonly composed of granitic and gneissic rocks with low topography, usually provide quartz rich and subarkose sandstones. In the LmLvLs plot, the samples fall in suture belt field (Fugure 4C) indicating that some sediments have also been derived from the uplited older sedimentary strata exposed in the kirthar fold belt [11]. In the QmPK plot it falls near to Qm end (Figure 4D) indicating derivation of the detritus from continental block [11]. The abundance of monocrystalline quartz with uniform extinction indicates that these sandstones were derived from granitic source $[17,18]$.

The presence of some of polycrystalline quartz consisting of more than 3 grains and undulose quartz grains suggest dervation from plutonic igneous and metamorphic rocks [14]. The presence of zircon inclusion in the quartz grains indicates derivation from plutonic felsic igneous rocks. The presence of albite plagioclase and alkali feldspar (orthoclase) suggest derivation of sediments from plutonic felsic igneous rock. The presence of microcline indicates that derivation of the sediments from felsic plutonic igneous and metamorphic rocks. The presence of mica (biotite and muscovite) indicates derivation from metamorphic anf igneous plutonic felsic rocks [21-25]. The presence of some lithic fragments such as siltstones, limestones chert indicate derivation of some sediment from older sedimentary rocks. The paleocurrent direction recorded from the flutes show that the flow was from southwest. This indicates that source area was to the northeast of the Nari Basin. It is envisaged that the Indian Craton to the NE have provided sediments for the Nari Formation with minor contribution from nearby exposed sedimentary rocks [26,27].
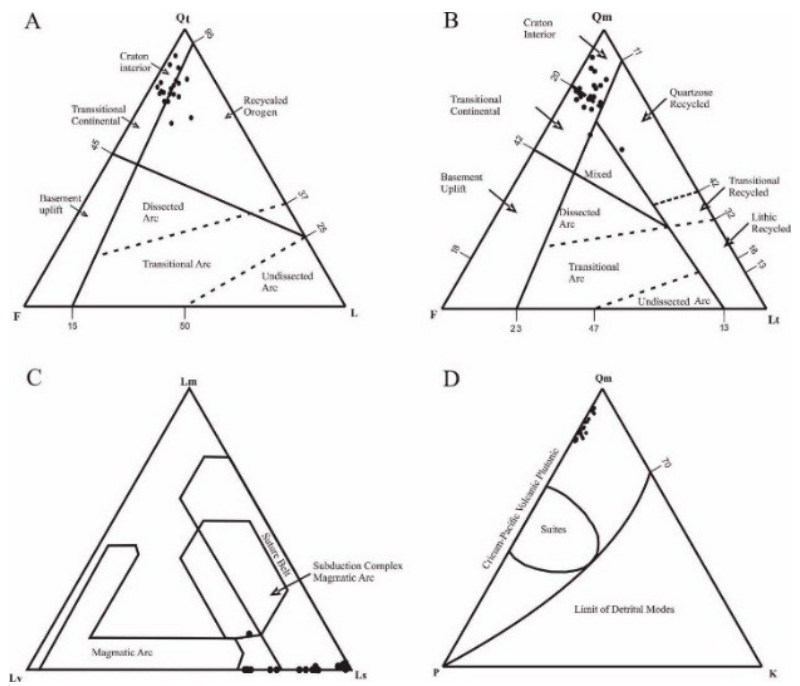
Figure 4: A- QtFL, B-QmFLt, C-LmLvLS and D-QmPK ternary diagrams for provenance tectonic setting of the Nari Formation [16].

\subsection{Conclusions}

Following conclusions can be drawn from the petrographic analysis of sandstones of the Nari Formation:

1. The sandstones are texturally and compositionally submature and moderately sorted indicating high relief, rapid erosion in the source area and short transport distance from source area.

2. The sandstones are subarkose and lithic subarkose. These sandstones are rich in quartz (36\% to 76\%) with subordinate feldspar (7-17\%) and minor amount of lithic fragment (1-13\%). The absence of distinctive variation in the composition of these sandstones indicate homogenous source.

3. The detrital mineral components indicate that these sandstones mostly were derived from acidic igneous granitic source with partial contribution from metamorphic and sedimentary rocks.

4. The Ternary Tectonic diagrams and paleocurrent direction reveal that the Indian Craton present to the northeast of the stu dy area is believed to be the major source area with minor contribution from locally exposed sedimentary rocks.

\subsection{Acknowledgement}

The present research work is part of the M.Phil thesis of Mr. Zahoor Ahmed which was completed in the Centre of Excellence in Mineralogy, University of Balochistan Quetta. The authors are thankful to the Director of the Centre for providing financial support for field work and laboratory facilities for analyses. The authors are also grateful to Mr. Zahoor Ahmed, Technician for his help in making thin sections.

\subsection{Conflict of Interest}

There is no conflict of interest among the authors

\subsection{References}

[1] A. Fatmi, I. Hyderi, and M. Anwar, "Occurrence of the Lower Jurassic Ammonoid genus Bouleiceras from the surghar range with a revised nomenclature of the Mesozoic Rocks of the Salt Range and Trans Indus Ranges (Upper Indus Basin)", Geol. Bull. Punjab Univ., Vol. 25, Pp. 38-46, 1990.

[2] M. Anwar, "Revised nomenclature and stratigraphy of Ferozabad, Alozai and Mona Jhal Groups of Balochistan (Axial Belt), Pakistan", Acta Mineral. Pakistan, Vol. 5, Pp. 46-61, 1991.

[3] S.M.I. Shah, "Stratigraphy of Pakistan, Stratigraphic Committee of Pakistan", Memoirs of Geol. Of Pakistan, Vol. 12, Pp. 1-15, 1977.

[4] M.D. Williams, "Stratigraphy of the Lower Indus Basin, West Pakistan", In 5th World petroleum congress, World Petroleum Congress, 1959.

[5] M. Umer, "Depositional environments of Campanian-Mastrichtian succession in the Kirthar foldbelt, southwest Pakistan; Tectonic influences on Late Cretaceous sedimentation across the Indian Passive Margin", Sedimentary Geology. Sedimentary Geology, Vol. 237, Pp. 30-45, 2011.

[6] M. Umer, "Sediments composition and provenance of Pab Formation, Kirthar Foldbelt, Pakistan: signatures of Hot Spot Volcanism, source area weathering and paleogeography on western Passive margin of Indian plate, Late Cretaceous", Arabian Journal of Science and Engineering, Vol. 39, Pp. 311-324, 2014.

[7] R. Hedley, "Sequence Stratigraphy and Tectonics in the Kirthar Fold Belt, Pakistan", Proceeding of of the SPE-PAPG Annual Technical Confeence Islamabad, Pp. 61-72, 2001.

[8] M. Cheema, "Cenozoic Stratigraphy of Pakistan", Memoirs of the Geological Survey of Pakistan, Quetta, Vol. 12, Pp. 1-138, 1977.

[9] A. Jones, "Reconnaissance Geology of part of West Pakistan, a Columbo Plan cooperative project", Hunting Survey Corporation, Government of Canada, Toronto, 1961.

[10] W.R. Dickinson, and C.A. Suczek, "Plate tectonics and sandstone compositions”, AAPG Bulletin, Vol. 63, No. 12, Pp. 2164-2182, 1979.

[11] W.R. Dickinson, "Provenance of North American Phanerozoic sandstones in relation to tectonic setting", Geological Society of America Bulletin, Vol. 94, No. 2, Pp. 222-235, 1983.

[12] R.V. Ingersoll, "The effect of grain size on detrital modes: a test of the Gazzi-Dickinson point-counting method", Journal of Sedimentary Research, Vol. 54, No. 1, Pp. 103-116, 1984.

[13] F.J. Pettijohn, "Sedimentary rocks". Vol. 3. 1975: Harper \& Row New York.

[14] R.L. Folk, “Petrology of sedimentary rocks: Austin”. Texas, Hemphill, Pp. 182, 1974.

[15] S.A. Mahmud, and S.A. Sheikh, "Reservoir potential of lower nari sandstones (Early Oligocene) in southern Indus basin and Indus offshore", In Annual Technical Conference (ATC), 2009.

[16] W.R. Dickinson, “Interpreting provenance relations from detrital modes of sandstones, in Provenance of arenites”, Springer, Pp. 333-361, 1985.

[17] G.G. Zuffa, “Optical analyses of arenites: influence of methodology on compositional results, in Provenance of arenites”, Springer. Pp. 165-189, 1985.

[18] E. Garzanti, "Non-carbonate intrabasinal grains in arenites; their recognition, significance, and relationship to eustatic cycles and tectonic setting", Journal of Sedimentary Research, Vol. 61, No. 6, Pp. 959-975, 1991.

[19] A.C. Morton, "Geochemical studies of detrital heavy minerals and their application to provenance research", Geological Society, London, Special Publications, Vol. 57, No. 1, Pp. 31-45, 1991.

[20] E.F. Mcbride, "Diagenetic processes that affect provenance determinations in sandstone, in Provenance of arenites", Springer. Pp. 95-113, 1985.

[21] L.J. Suttner, and P.K. Dutta, "Alluvial sandstone composition and paleoclimate; I, Framework mineralogy", Journal of Sedimentary Research, Vol. 56, No. 3, Pp. 329-345, 1986. 
[22] S. Critelli, E. Le Pera, and R.V. Ingersoll, "The effects of source lithology, transport, deposition and sampling scale on the composition of southern California sand", Sedimentology, Vol. 44, No. 4, Pp. 653-671, 1997.

[23] E. Garzanti, "Provenance of passive-margin sand (Southern Africa)”, The Journal of Geology, Vol. 122, No. 1, Pp. 17-42, 2014.

[24] F. Bender, H. Raza, and D. Bannert, “Geology of Pakistan: Gebruder Borntraeger”, Germany, 1995.

[25] A. Basu, "Re-evaluation of the use of undulatory extinction and polycrystallinity in detrital quartz for provenance interpretation", Journal of Sedimentary Research, Vol. 45, No. 4, Pp. 873-882, 1975.

[26] A. Basu, "Petrology of Holocene fluvial sand derived from plutonic source rocks; implications to paleoclimatic interpretation", Journal of Sedimentary Research, Vol. 46, No. 3, Pp. 694-709, 1976.

[27] S. Shah, "Stratigraphy of Pakistan", Geol. Surv. Pakistan, Pp. 138, 1977. 